universities, since industry is the controlling factor of modern life. Industry must learn what the universities do and how graduates can be introduced, particularly into small firms. The universities must learn to appreaiate the nature and purpose of industry. $\mathrm{He}$ pointed out that the cessation of ear-marked grants throws an increased responsibility on the universities, since they must not neglect the needs of industry.

Prof. W. G. Sutton, Witwatersrand, claimed that in the technological field his university has the same aims as Cambridge. He feels that too much respect for research must not be encouraged among students of technology, but that postgraduate courses of instruction are desirable. He ended with a warning to New South Wales that South Africa from bitter experience knows the deficiencies of technological institutions as centres of higher education.

Prof. J. R. Daymond, Natal, in his turn claimed allegiance to the Cambridge aims. The University of Natal encourages students to graduate in science and then to read engineering for two further years. Prof. Daymund, taking more than twice the allowance of time given to other speakers, pleaded eloquently for a broader base to be given to the educational pyramid and for universities to resist the tendency to train in specific skills.

Prof. W. H. Hutt, Cape Town, who stressed the fact that he is not an engineer, expressed entire agreement with the views Prof. Baker expressed in opening the session, and summed up the discussion in the apt phrase, "Let the university teach 'why' and leave life to teach "how'",

\section{ACADEMIC MOBILITY IN THE BRITISH COMMONWEALTH}

\author{
BY SIR CHARLES MORRIS \\ Vice-Chancellor, University of Leeds
}

$\mathrm{A}^{\mathrm{T}}$ T the recent Congress of Universities of the Commonwealth at Cambridge, at which more than eighty universities and university colleges were represented, there was a lively and most interesting discussion on "Academic Mobility in the Commonwealth". A previous Congress five years ago at Oxford had pressed for vigorous action to be taken to promote interchange of both senior and junior scholars between British countries; and following that Congress the United Kingdom Government made available through the British Council rather more than $£ 30,000$, so that a start could be made with the pilot scheme. Under this scheme, provision was made for three categories of scholars: very senior and distinguished people paying short visits on the invitation usually of several universities; professors and other established scholars on leave from their own universities for about a year ; and junior scholars able to spend one or two years abroad at the beginning of their professional academic careers. It was clear from the discussion at the Congress that the minds of the universities in other Commonwealth countries have been working along the same lines, and a great deal of progress has been made in many countries.

The British Council scheme clearly covers only a part of the total movement between universities, but its role was recognized to be an extremely valuable one; the Congress showed itself particularly interested in the visits arranged in the first category mentioned above, namely, the short visits of very senior and distinguished people. In the meantime, it was obvious that there are some most desirable developments not covered or certainly not sufficiently covered by any of the arrangements in operation within the Commonwealth-in particular, movement between the universities and university colleges in the Colonial countries and the rest of the Commonwealth, and cross-movement between the 'peripheral' countries of the Commonwealth themselves. On the first point it was announced to the Congress that the United Kingdom Government has now made a fund available to enable similar arrangements to be made with the university institutions of the Colonial countries.

After a lively debate the Congress passed a resolution urging member universities to seek suitable opportunities for approaching their Governments with the request that they should contribute to "a co-operatively administered Commonwealth Interchange Fund". It need not be said that the Congress showed itself well aware of the high desirability of movement between the universities of British countries and of non-British countries, notably the countries of Western Europe and the United States. Tribute was paid especially to the success of the Fulbright scheme.

This was perhaps the most interesting instance of a resolution of the last Congress five years ago being actually brought into force. It was a significant instance. The zeal for promoting movement between universities has greatly increased in the past five years. Many speakers at the Cambridge meoting testified to the great value of interchange of undergraduates and young graduates; and a great deal of thought was given to the well-known problems involved in making it easier for members of the academic staff of a university in one country to move to a permanent appointment in another country. There was no kind of suggestion by anybody that too much importance was being attached to such movement or that the zeal for these developments was getting out of proportion. The only hesitant voices were from those who feared that movement between British and non-British universities might possibly suffer. There is no question that the Congress as a whole was most desirous that this should not be so.

\section{THE UNIVERSITY OF LIVERPOOL (1903-53) \\ BY SIR HENRY COHEN \\ Professor of Medicine, University of Liverpool}

T'T is a happy circumstance that this year's meeting 1 in Liverpool of the British Association for the Advancement of Science should coincide with the jubilee of the granting of the Charter to the University of Liverpool. For the story of the University's first fifty years is an enviable record both of notable men of science and of man's successful quest for knowledge. A University College had existed for twentyone years before full university status was attained, and had been served by many impressive scientific figures, including Oliver Lodge who, after occupying the Lyon Jones chair of physics for nineteen years, had resigned to become the first principal of the University of Birmingham. 